\title{
Association between long working hours and serum gamma-glutamyltransferase levels in female workers: data from the fifth Korean National Health and Nutrition Examination Survey (2010-2011)
}

\author{
Seung-Gwon Park, Yong-Jin Lee, Jung-Oh Ham, Eun-Chul Jang*, Seong-Woo Kim and Hyun Park
}

\begin{abstract}
Objectives: The present study investigated the association between long working hours and serum gammaglutamyltransferase (GGT) levels, a factor influencing the incidence of cardiovascular disease.

Methods: Data from the fifth Korean National Health and Nutrition Examination Survey (2010-2011) were used to analyze 1,809 women. Subjects were divided into three groups based on the number of weekly working hours: $\leq 29$, $30-51$, and $\geq 52$ hours per week. Complex samples logistic regression was performed after adjusting for general and occupational factors to determine the association between long working hours and high serum GGT levels.

Results: The prevalence of high serum GGT levels in groups with $\leq 29,30-51$, and $\geq 52$ working hours per week was $22.0 \%, 16.9 \%$, and 26.6\%, respectively. Even after adjusting for general and occupational factors, those working 30-51 hours per week had the lowest prevalence of high serum GGT levels. Compared to those working 30-51 hours per week, the odds ratios (OR) of having high serum GGT levels in the groups with $\geq 52$ and $\leq 29$ working hours per week were 1.56 (95\% confidence interval [Cl], 1.10-2.23) and 1.53 (95\% Cl, 1.05-2.24), respectively.
\end{abstract}

Conclusions: Long working hours were significantly associated with high serum GGT levels in Korean women.

Keywords: Long working hours, Gamma-glutamyltransferase, Cardiovascular disease

\section{Introduction}

Long working hours lead to poor health habits such as smoking and alcohol consumption as well as sleep deprivation and excessive stress. In turn, these poor habits adversely affect different aspects of health, including the cardiovascular, gastrointestinal, and immune systems as well as mental health [1-3]. Among several negative health consequences, cardiovascular disease and its risk factors are the primary focus of many studies. Thus far, studies on the risk factors of cardiovascular diseases indicate long working hours are associated with increased

\footnotetext{
*Correspondence: oemdr10@gmail.com

Department of Occupational \& Environmental Medicine, Soonchunhyang University Cheonan Hospital, 31, Soonchunhyang 6-gil, Dongnam-gu, Cheonan-si, Chungcheongnam-do 330-930, Republic of Korea
}

incidence rates of high blood pressure, diabetes, acute myocardial infarction, and coronary artery disease [4-8].

Caruso et al. [3] reported that two reasons for long working hours include a workers' desire to increase their earnings as well as a tendency of employers to keep costs low by avoiding hiring additional employees. In addition, Artazcoz et al. [9] suggested that the stresses of being a breadwinner and economic vulnerability are important causes of long working hours. Because the overtime pay rate is high in the Republic of Korea (hereafter Korea), Korean workers have a strong preference for working overtime. Moreover, the lack of flexibility in hiring practices as well as good fringe benefits collectively discourages employers' from hiring additional employees. As such, the culture of long working hours is much more prevalent in Korea than other countries [10]. Furthermore, 
female workers in Korea generally shoulder the bulk of domestic work in their families. In fact, female workers in Korea spend 3-6 times longer on domestic work than their male counterparts do [11]; moreover, the duration of domestic work performed by Korean men is the shortest among all Organization for Economic Co-operation and Development (OECD) countries [12]. Despite the high prevalence of long working hours among women, most studies on long working hours have exclusively focused on men [13].

Gamma-glutamyltransferase (GGT) has been used as a biomarker of alcohol intake and hepatocellular damage [14]. However, recent reports suggest GGT is also a biomarker of oxidative stress [15]. Oxidative stress is involved in the pathophysiology of cardiovascular disease; therefore, serum GGT has been receiving increasing attention as a potential early indicator of cardiovascular disease [16-18]. We investigated the relationship between long working hours and serum GGT levels in Korean women.

\section{Materials and Methods Subjects}

The Korean National Health and Nutrition Examination Survey (KNHANES) uses a rolling survey sampling wherein the samples of each year serve as an independent probability sampling pool and the samples sharing similar characteristics in each sample year are selected. To collect a representative Korean population, a stratified multistage-clustered probability design is used to sample enumeration districts. The enumeration districts were created as follows. First, the cities and provinces of Korea were stratified. Then, the general housing area was stratified into 26 levels with respect to sex, age group, and population ratio. Apartment complex areas were stratified into 24 levels according to the price per square meter and average number of square meters per apartment. After residences were subjected to this 2stage stratification, 20 residence units were extracted per enumeration district; thus, a total of 3,840 residences were extracted from 192 enumeration districts.

The KNHANES comprises health, clinical examination, and nutritional surveys. While health and nutrition surveys were conducted by trained investigators, the health behavior aspects of the health survey including smoking status and alcohol consumption were assessed using self-reported data.

Data from the fifth KNHANES (2010-2011) were used because serum GGT levels were only collected during this period. Among the study population of 21,527 people, this study involved 16,528 participants (participation rate, 76.7\%). Among 1,905 pre-menopausal women between 20 and 49 years old who were employed, 54 women with hepatitis B or C, or liver cirrhosis as well as 42 with alanine aminotransferase levels $\geq 36$ IU/L were excluded to avoid the confounding effect of liver disease. Thus, a total of 1,809 women were analyzed.

\section{Measures}

In order to measure serum GGT (dependent variable), an enzymatic activity assay (G5CMP) was performed using the Hitachi Automatic Analyzer 7600 (Hitachi, Japan). Participants with serum GGT levels $\leq 20$ and $\geq 21$ IU/L were classified as the normal and high serum GGT groups, respectively [19]. Working hours per week (independent variable) was classified into three groups: $\leq 29$ hours (defined as part-time employment by the OECD) [20], 30-51 hours, and $\geq 52$ hours (defined as long working hours by the Labor Standards Act in Korea) [21].

Age was categorized between 20-39 or 40-49 years. Body mass index (BMI) was categorized as $<18.5$ (underweight), 18.5-22.9 (normal), or $\geq 23$ (overweight) $\mathrm{kg} / \mathrm{m}^{2}$. The volume and frequency of alcohol consumption were asked using closed-ended questions; therefore, to calculate weekly alcohol consumption, the mean volume and frequency of alcohol consumption were multiplied. The products were categorized as $\leq 2.5$ or $>2.5$ standard-sized drinks per week. In addition, participants were categorized as non-smokers, ex-smokers, or current smokers. The number of hours sleep per day was categorized as $\leq 5,6-8$, or $\geq 9$ hours. Walking at least 30 minutes per day 5 days per week was considered regular walking. The frequency of coffee consumption was categorized as $<1$ or $\geq 1$ cup of coffee per day. Work performed between 6:00 AM to 6:00 PM was categorized as day work, and work performed outside this time was categorized as non-day work. Moreover, participants were classified as salary workers, being self-employed, or unpaid family workers. Manual work included agricultural forestry and fishery work, crafts and related trades, equipment, machine operation and assembly, and elementary work. All other occupations were categorized as non-manual work.

\section{Statistical analysis}

Because the KNHANES uses a complex sample design, a survey module for complex samples and survey weights were applied. To analyze the characteristics of the study population and factors influencing serum GGT levels, a complex samples $X^{2}$ tests were performed to calculate estimated percentages. In addition, complex samples logistic regression was performed to calculate odds ratios (OR) and 95\% confidence intervals (CI) of high serum GGT levels after adjusting for variables significantly associated with GGT levels in the univariate analysis and work type. All statistical analyses were performed using SPSS version 18.0 (SPSS Inc., Chicago, IL, USA), and the level of significance was set at $p<0.05$. 


\section{Results}

\section{General and occupational characteristics}

The distribution of working hours per week included 400 (21.0\%), 1,054 (57.8\%), and 355 (21.2\%) women who worked $\leq 29,30-51$, and $\geq 52$ hours per week, respectively. Those aged 40-49 tended to be the most likely to work $\geq 52$ hours per week (41.4\%). BMI did not differ significantly among groups. The proportions of women with $>2.5$ alcoholic drinks per week (37.9\%), currently smoking (13.7\%), and sleeping $<5$ hours of per night (9.4\%) were higher among those working $\geq 52$ hours per week than that of other groups. Non-day workers was in the $\leq 29$ hour group (32.9\%), and salary workers were commonly worked 30-51 hours per week (81.9\%). There were no significant differences between occupations and working hours per week (Table 1).

\section{General characteristics and high serum GGT levels}

The prevalence of high serum GGT levels in women aged 20-39 and 40-49 years was $16.6 \%$ and $26.4 \%$, respectively. Moreover, the prevalence of high serum GGT levels in underweight, normal, and overweight subjects was $11.2 \%$, $15.5 \%$, and $42.5 \%$, respectively. For alcohol consumption, high serum GGT levels was significantly more prevalent among subjects who consumed $>2.5$ drinks per week (26.4\%) than those who consumed $\leq 2.5$ drinks per week (16.8\%). In addition, a high serum GGT level was more prevalent in current smokers (40.4\%) than ex-smokers (18.4\%) and non-smokers (17.9\%). Women who did not walk regularly had higher serum GGT levels than those who walked regularly did (22.0\% vs. $16.8 \%)$. However, high serum GGT was not significantly different across sleep duration or caffeine intake groups (Table 2).

\section{Occupational characteristics and high serum GGT levels}

The prevalence of high serum GGT levels was the lowest among subjects working 30-51 hours per week (16.9\%) followed by those working $\leq 29$ hours per week (22.0\%) and $\geq 52$ hours per week (26.6\%). In addition, salary workers exhibited the lowest prevalence of high serum GGT levels (16.8\%). However, no significant differences across occupation or working type groups and serum GGT levels were found (Table 3).

\section{Working hours and high serum GGT levels}

Compared to those working 30-51 hours per week, the OR of having high serum GGT levels among those working $\leq 29$ and $\geq 52$ hours per week were 1.39 (95\% CI, $0.99-1.94$ ) and 1.78 (95\% CI, 1.30-2.44), respectively. Model 1, adjusted for general characteristics (age, BMI, alcohol consumption, smoking status, and regular walking), the OR of having high serum GGT levels among those working $\leq 29$ and $\geq 52$ working hours per week were 1.51 (95\% CI, 1.03-2.19) and 1.52 (95\% CI, 1.07-
2.15) respectively. Model 2, adjusted for the variables from model 1 as well as work type and employment status, the OR were 1.53 (95\% CI, 1.05-2.24) and 1.56 (95\% CI, 1.10-2.23) among those working $\leq 29$ and $\geq 52$ working hours per week, respectively (Table 4).

\section{Discussion}

Among Korean female workers, the prevalence of high serum GGT levels was higher among those working long hours ( $\geq 52$ hours per week) than those working 30-51 hours per week even in the fully adjusted model.

The definition of long working hours varies by country and institution. The Labor Standards Act in Korea has set the weekly working hours at $<40$ hours and $<52$ hours including overtime [21]. However, the International Labor Organization and the European Union define 48 hours as appropriate number of weekly working hours [22,23]. According to the 2012 survey in Korea on labor conditions by employment type, the average monthly working hours was 173.7 [24]. One report from the OECD indicates the annual working hours of Koreans has decreased steadily from a peak of 2,512 hours in 2000; however, Koreans still have the longest annual working hours among all OECD countries, with 2,193 hours in 2010 [25].

Many recent studies have investigated the influence of long weekly working hours on cardiovascular health. Hayashi et al. [5] reported that 24-hour ambulatory blood pressure is higher among office workers with long weekly working hours than among office workers in their control group. Iwasaki et al. [4] reported that certain age groups have increased systolic blood pressure because of increased fatigue due to long weekly working hours. In addition, Kawakami et al. [6] found that working $>50$ hours per week increases the risk of contracting non-insulin-dependent diabetes by 3.7 fold, and a metaanalysis by Virtanen et al. [8] revealed that long weekly working hours increases the risk of coronary artery disease by approximately 1.4 fold.

Long working hours can affect an individual's health in several ways. By working long hours, an individual can experience physiological changes in blood pressure, hormone excretion, and sympathetic nervous system activity among others. Furthermore, long working hours can result in negative lifestyle behaviors such as alcohol consumption, smoking, an unhealthy diet, and a lack of exercise. Thus, the combination of negative physiological and lifestyle changes can collectively increase one's risk of cardiovascular disease [1]. The present study also revealed high prevalences of smoking, drinking, and inadequate sleep duration in those working $\geq 52$ hours per week. Shields et al. [26] reported that increased working hours are associated with increased alcohol consumption in women. In addition, Steptoe et al. [27] reported that women who work long hours tend to smoke more 
Table 1 General and occupational characteristics

\begin{tabular}{|c|c|c|c|c|c|}
\hline \multirow{2}{*}{ Variables } & \multirow{2}{*}{ Total } & \multicolumn{3}{|c|}{ Weekly working hours } & \multirow{2}{*}{$P$-value ${ }^{\dagger}$} \\
\hline & & $\leq 29 \mathrm{~N}(\% *)$ & $30-51 \mathrm{~N}\left(\%^{*}\right)$ & $\geq 52 \mathrm{~N}(\% *)$ & \\
\hline Total & $1,809(100.0)$ & $400(21.0)$ & $1,054(57.8)$ & $355(21.2)$ & \\
\hline \multicolumn{6}{|l|}{ Age (years) } \\
\hline $20-39$ & $1,150(65.0)$ & $256(64.8)$ & $691(67.5)$ & $203(58.6)$ & \multirow[t]{2}{*}{0.039} \\
\hline $40-49$ & $659(35.0)$ & $144(35.2)$ & $363(32.5)$ & $152(41.4)$ & \\
\hline \multicolumn{6}{|l|}{ BMI $\left(\mathrm{kg} / \mathrm{m}^{2}\right)$} \\
\hline Underweight $(<18.5)$ & $182(10.8)$ & $38(10.3)$ & $120(12.2)$ & $24(7.4)$ & \multirow[t]{3}{*}{0.172} \\
\hline Normal (18.5-22.9) & $1,307(71.1)$ & $290(70.6)$ & $765(71.1)$ & $252(71.4)$ & \\
\hline Overweight ( $\geq 23.0$ ) & $317(18.1)$ & $70(19.1)$ & $169(16.7)$ & $78(21.2)$ & \\
\hline \multicolumn{6}{|c|}{ Alcohol consumption (glasses/week) } \\
\hline$\leq 2.5$ & $1,217(66.3)$ & $291(72.5)$ & $708(65.5)$ & $218(62.1)$ & \multirow[t]{2}{*}{0.035} \\
\hline$>2.5$ & $592(33.7)$ & $109(27.5)$ & $346(34.5)$ & $137(37.9)$ & \\
\hline \multicolumn{6}{|l|}{ Smoking status } \\
\hline Non-smoker & $1,532(82.3)$ & $343(86.1)$ & $904(82.4)$ & $285(78.3)$ & \multirow[t]{3}{*}{0.040} \\
\hline Ex-smoker & $136(8.5)$ & $30(8.0)$ & $76(8.8)$ & $30(8.0)$ & \\
\hline Current smoker & $141(9.2)$ & $27(5.8)$ & $74(8.8)$ & $40(13.7)$ & \\
\hline \multicolumn{6}{|l|}{ Sleep duration (hours/day) } \\
\hline$\leq 5$ & $151(9.0)$ & $30(8.7)$ & $85(9.0)$ & $36(9.4)$ & \multirow[t]{3}{*}{0.028} \\
\hline $6-8$ & $1,527(83.5)$ & $327(79.4)$ & $897(83.9)$ & $303(86.5)$ & \\
\hline$\geq 9$ & $131(7.5)$ & $43(11.9)$ & $72(7.2)$ & $16(4.1)$ & \\
\hline \multicolumn{6}{|l|}{ Regular walking } \\
\hline Yes & $658(37.3)$ & $152(40.6)$ & $388(37.9)$ & $118(32.5)$ & \multirow[t]{2}{*}{0.135} \\
\hline No & $1,150(62.7)$ & $248(59.4)$ & $665(62.1)$ & $237(67.5)$ & \\
\hline \multicolumn{6}{|l|}{ Coffee intake (cups/day) } \\
\hline$<1$ & $504(37.8)$ & $87(31.2)$ & $304(39.2)$ & $113(40.2)$ & \multirow[t]{2}{*}{0.130} \\
\hline$\geq 1$ & $840(62.2)$ & $200(68.8)$ & $479(60.8)$ & $161(59.8)$ & \\
\hline \multicolumn{6}{|l|}{ Working type } \\
\hline Day work & $1,478(81.6)$ & $281(67.1)$ & 907 (85.6) & $290(85.0)$ & \multirow[t]{2}{*}{$<0.001$} \\
\hline Non-day work & $317(18.4)$ & $117(32.9)$ & $141(14.4)$ & $59(15.0)$ & \\
\hline \multicolumn{6}{|l|}{ Occupation } \\
\hline Manual work & $266(15.6)$ & $61(16.4)$ & $145(14.8)$ & $60(17.1)$ & \multirow[t]{2}{*}{0.633} \\
\hline Non-manual work & $1,542(84.4)$ & $339(83.6)$ & $909(85.2)$ & $294(82.9)$ & \\
\hline \multicolumn{6}{|l|}{ Employment status } \\
\hline Salary worker & $1,127(73.8)$ & $206(64.7)$ & $746(81.9)$ & $175(60.8)$ & \multirow[t]{3}{*}{$<0.001$} \\
\hline Self-employed & $289(19.1)$ & $87(26.1)$ & $108(13.1)$ & $94(28.3)$ & \\
\hline Unpaid family worker & $107(7.2)$ & $26(9.2)$ & $42(5.0)$ & 39 (10.9) & \\
\hline
\end{tabular}

*Estimate percentage.

${ }^{+} X^{2}$ test.

cigarettes. Virtanen et al. [28] found that people working $>55$ hours per week not only slept fewer hours per day, but also experience difficulty falling asleep.

Serum GGT activity is elevated when glutathione, an antioxidant, exerts its cytoprotective effect by inhibiting free radicals produced by oxidative stress [14]. Increasing evidence indicating that serum GGT is a biomarker of oxidative stress [15] consequently revealed that serum GGT is associated with diseases including high blood pressure, diabetes, metabolic syndrome, stroke, and coronary artery disease. Moreover, serum GGT may explains their respective pathogenesis [16-18,29]. Interest in serum GGT has been further amplified because of its association with other early predictors of cardiovascular disease, including 
Table 2 Prevalence of high serum gammaglutamyltransferase levels across general characteristics

\begin{tabular}{llll}
\hline \multirow{2}{*}{ Variable } & \multicolumn{2}{l}{ Serum GGT* } & \\
\cline { 2 - 3 } & $\begin{array}{l}\text { Normal level } \\
\text { group }\end{array}$ & $\begin{array}{l}\text { High level } \\
\text { group }\end{array}$ \\
& $\mathbf{N}\left(\%^{\ddagger}\right)$ & $\mathbf{N}\left(\%^{\ddagger}\right)$ & \\
\hline Total & $1,470(80.0)$ & $339(20.0)$
\end{tabular}

Age (years)

$\begin{array}{llll}20-39 & 974(83.4) & 176(16.6) & <0.001 \\ 40-49 & 496(73.6) & 163(26.4) & \end{array}$

BMl $\left(\mathrm{kg} / \mathrm{m}^{2}\right)$

$\begin{array}{lll}\text { Underweight }(<18.5) & 158(88.8) & 24(11.2) \\ \text { Normal }(18.5-22.9) & 1,113(84.5) & 194(15.5) \\ \text { Overweight }(\geq 23.0) & 197(57.5) & 120(42.5)\end{array}$

Alcohol consumption (glasses/week)

$\begin{array}{cccc}\leq 2.5 & 1,029(83.2) & 188(16.8) & <0.001 \\ >2.5 & 441(73.6) & 151(26.4) & \\ \text { Smoking status } & & \end{array}$

$\begin{array}{llll}\text { Non-smoker } & 1,271(82.1) & 261(17.9) \quad<0.001 \\ \text { Ex-smoker } & 112(81.6) & 24(18.4) & \\ \text { Current smoker } & 87(59.6) & 54(40.4)\end{array}$

Sleep duration (hours/day)

$\begin{array}{lll}\leq 5 & 114(74.3) & 37(25.7) \\ 6-8 & 1,251(80.6) & 276(19.4) \\ \geq 9 & 105(79.5) & 26(20.5)\end{array}$

Regular walking

Yes

$553(83.2) \quad 105(16.8)$

0.030

No

$916(78.0) \quad 234(22.0)$

Coffee intake (cups/day)

\begin{tabular}{llll}
$<1$ & $405(79.3)$ & $99(20.7)$ & 0.471 \\
$\geq 1$ & $687(81.3)$ & $153(18.7)$ & \\
\hline
\end{tabular}

*Gamma-glutamyltransferase.

†'Serum GGT $\geq 21$ IU/L.

${ }^{\ddagger}$ Estimated percentage

${ }^{5} x^{2}$ test.

high-sensitivity C-reactive protein, pulse wave velocity, and the Framingham risk score [30,31].

In addition to conventional well-known factors (age, sex, and alcohol consumption), obesity, smoking, and physical activity also influence serum GGT levels. The present study corroborates obesity as a factor influencing GGT levels, because the overweight group exhibited the highest prevalence of high serum GGT levels. Furthermore, current smokers exhibited a higher prevalence of high serum GGT levels than ex- and non-smokers did. The prevalence of high serum GGT levels was significantly lower in regular walkers than in non-regular walkers, which is similar to the results of the study by Nilssen et al. [32]. Although previous studies report that
Table 3 Prevalence of high serum gammaglutamyltransferase levels across occupational characteristics

\begin{tabular}{|c|c|c|c|}
\hline \multirow{3}{*}{ Variable } & \multicolumn{2}{|l|}{ Serum GGT* } & \multirow{3}{*}{$p$-value } \\
\hline & $\begin{array}{l}\text { Normal level } \\
\text { group }\end{array}$ & $\begin{array}{l}\text { High level } \\
\text { group }^{+}\end{array}$ & \\
\hline & $N\left(\%^{\ddagger}\right)$ & $\mathrm{N}\left(\%^{\ddagger}\right)$ & \\
\hline \multicolumn{4}{|l|}{$\begin{array}{l}\text { Weekly working } \\
\text { hours }\end{array}$} \\
\hline$\leq 29$ & $321(78.0)$ & $79(22.0)$ & 0.002 \\
\hline $30-51$ & $882(83.1)$ & $172(16.9)$ & \\
\hline$\geq 52$ & $267(73.4)$ & $88(26.6)$ & \\
\hline \multicolumn{4}{|l|}{ Working type } \\
\hline Day work & $1,200(79.9)$ & $278(20.1)$ & 0.820 \\
\hline Non-day work & $261(80.6)$ & $56(19.4)$ & \\
\hline \multicolumn{4}{|l|}{ Occupation } \\
\hline Manual work & $212(78.2)$ & $54(21.8)$ & 0.489 \\
\hline Non-manual work & $1,257(80.3)$ & $285(19.7)$ & \\
\hline \multicolumn{4}{|l|}{ Employment status } \\
\hline Salary worker & $947(83.2)$ & $180(16.8)$ & $<0.001$ \\
\hline Self-employed & $218(71.6)$ & $71(28.4)$ & \\
\hline $\begin{array}{l}\text { Unpaid family } \\
\text { worker }\end{array}$ & $75(70.0)$ & $32(30.0)$ & \\
\hline
\end{tabular}

coffee consumption is inversely associated with serum GGT levels [32,33], the present study found no significant association. The mechanism by which coffee reduces serum GGT levels is not fully understood; Nilssen et al. [32] also claim that different types of coffee (e.g., boiled, filtered, and instant) can have different effects on serum GGT levels.

In the present study, we found no significant difference in the prevalence of high serum GGT levels between day and non-day workers; this finding is concordant with those of Higashikawa et al. [34] and Knutsson et al. [35]. However, $70.0 \%$ of women who performed non-day work

Table 4 Associations between weekly working hours and high serum gamma-glutamyltransferase levels

\begin{tabular}{|c|c|c|c|c|c|c|}
\hline \multirow{2}{*}{$\begin{array}{l}\text { Working } \\
\text { hours/week }\end{array}$} & \multicolumn{2}{|c|}{ Crude } & \multicolumn{2}{|c|}{ Model $1^{*}$} & \multicolumn{2}{|c|}{ Model $2^{\dagger}$} \\
\hline & $\overline{\mathrm{OR}^{\ddagger}}$ & $95 \% \mathrm{Cl}^{\S}$ & $\overline{\mathrm{OR}^{\ddagger}}$ & $95 \% \mathrm{Cl}^{\S}$ & $\overline{\mathrm{OR}^{\ddagger}}$ & $95 \% \mathrm{Cl}^{\S}$ \\
\hline$\leq 29$ & 1.39 & $0.99-1.94$ & 1.51 & $1.03-2.19$ & 1.53 & $1.05-2.24$ \\
\hline $30-51$ & 1 & & 1 & & 1 & \\
\hline$\geq 52$ & 1.78 & $1.30-2.44$ & 1.52 & $1.07-2.15$ & 1.56 & $1.10-2.23$ \\
\hline
\end{tabular}

*Adjusted for general characteristics (i.e., age, BMI, alcohol consumption, smoking status and regular walking).

${ }^{\dagger}$ Adjusted for general and occupational characteristics (i.e., Model $1+$ working type, and employment status).

${ }^{\ddagger}$ Odds ratio, ${ }^{5} 95 \%$ confidence interval. 
performed evening work, while only $30.0 \%$ performed night work or regular shift work. Therefore, the classical health effects of atypical work hours may not be applicable to the present study population.

In the present study, women who worked $\leq 29$ hours per week were more likely to have high serum GGT levels than those who worked 30-51 hours did even after full adjustment. In their case-control study of 195 myocardial infarction patients, Sokejima et al. [10] found that patients who worked $<7$ and $>11$ hours per day had a higher risk of myocardial infarction than those who worked 7-9 hours per day did; thus, a U-shaped association between the number of daily working hours and risk of myocardial infarction was found. Morris et al. [36] also reported that decreased working hours due to unemployment could increase the risk of acute myocardial infarction. In addition, previously unhealthy individuals may have been overrepresented in the $\leq 29$ hours per week work group in the present study. Therefore, the relationship between low working hours and health should be a target of future prospective studies.

The present study has some limitations. First, this was a cross-sectional study, so a causal relationship between long working hours and high serum GGT levels cannot be suggested. Furthermore, although the effects of long working hours on serum GGT levels are understood to be chronic in nature, the present study could not determine an appropriate working period for studying the chronic effects of long working hours. Second, because there is no precise definition or diagnostic standard for high serum GGT levels, the cut-off of high serum GGT levels used in the present study ( $\geq 21 \mathrm{IU} / \mathrm{L})$ may not be a clinically accepted value. Thus, a different cut-off value may change our study findings. Lee et al. [15] reported a strong dose-response relationship of GGT levels within normal limits with oxidative stress and cardiovascular risk. However, to the best of our knowledge, there are no reports of a dose-response relationship between abnormal GGT levels and cardiovascular risk. Consequently, we used a relatively low cut-off to define high serum GGT to include both those with clinically abnormal levels and those with high GGT levels within reference range. In addition, because a comparison of the geometric means of serum GGT levels across the three groups showed results similar to those in this study, a different cut-off should not substantially alter the structure or results of the present study. Third, the present study targeted only women. Some studies have suggested that cardiovascular responses to stress differ between men and women [37]. Furthermore, the manifestations of stress-related behavioral changes may also differ between sexes [38]. Therefore, caution should be taken when applying the results of this study to men. Most conventional studies of long working hours and health have exclusively targeted men, and the few studies targeting women and their working hours involved only specific occupations. Therefore, the present study is meaningful because representative data on Korean women and a commonly used blood test parameter, serum GGT, were used to analyze the associations between long working hours and employee's health.

\section{Conclusion}

In conclusion, our study results suggest that long working hours are associated with high serum GGT levels in Korean women. Considering the results of many previous studies reporting an association between cardiovascular risk and serum GGT levels, serum GGT may be a useful biomarker for determining which employees require additional attention to their health. Thus, our study results have important implications in public health. Therefore, future, well-designed prospective studies addressing the aforementioned limitations of this study and those of previous studies are required to understand the relationship between these factors.

\section{Competing interests}

The authors declare that they have no competing interests.

\section{Authors' contributions}

$\mathrm{SGP}, \mathrm{YJ}, J \mathrm{OH}$ and ECJ designed the research, interpreted the data and wrote the manuscript. SWK and HP performed the statistical analysis. All authors read and approved the final manuscript.

\section{Acknowledgments}

This research was supported by Soonchunhyang University Research Fund.

Received: 26 March 2014 Accepted: 14 October 2014

Published online: 01 December 2014

\section{References}

1. van der Hulst M: Long work hours and health. Scand J Work Environ Health 2003, 29(3):171-188.

2. Rom WN, Markowitz SB: Environmental and Occupational Medicine. 4th edition. Philadelphia: Wolters Kluwer Health; 2007.

3. Caruso CC, Bushnell T, Eggerth D, Heitmann A, Kojola B, Newman K, Rosa RR, Sauter SL, Vila B: Long working hours, safety, and health: toward a National Research Agenda. Am J Ind Med 2006, 49(11):930-942.

4. Iwasaki K, Sasaki T, Oka T, Hisanaga N: Effect of working hours on biological functions related to cardiovascular system among salesmen in a machinery manufacturing company. Ind Health 1998, 36(4):361-367.

5. Hayashi T, Kobayashi Y, Yamaoka K, Yano E: Effect of overtime work on 24-hour ambulatory blood pressure. J Occup Environ Med 1996, 38(10):1007-1011.

6. Kawakami N, Araki S, Takatsuka N, Shimizu H, Ishibashi H: Overtime, psychosocial working conditions, and occurrence of non-insulin dependent diabetes mellitus in Japanese men. J Epidemiol Community Health 1999, 53(6):359-363.

7. Sokejima S, Kagamimori S: Working hours as a risk factor for acute myocardial infarction in Japan: case-control study. BMJ 1998, 317(7161):775-780.

8. Virtanen M, Heikkilä K, Jokela M, Ferrie JE, Batty GD, Vahtera J, Kivimäki M: Long working hours and coronary heart disease: a systematic review and meta-analysis. Am J Epidemiol 2012, 176(7):586-596.

9. Artazcoz L, Cortes I, Escriba-Aguir V, Cascant L, Villegas R: Understanding the relationship of long working hours with health status and healthrelated behaviours. J Epidemiol Community Health 2009, 63(7):521-527.

10. Cho KS: The systematic improvement measures to enhance long time working. J Law Res 2009, 25(4):249-273. Korean. 
11. Park JS, Institute for Health and Social Affairs: The Gendered Division of Domestic Labor With Respect to the Economic Activity Characteristics of the Sexes.(Translated by Park SG) Seoul, Korea. Korean; 2012:3. https://www. kihasa.re.kr/html/jsp/publication/periodical/focus/list.jsp?bid=21\&page=9 [cited on 11 May 2014].

12. OECD: OECD Family Database 2012. Paris, France: OECD Publishing; 2012:1-2. http://www.oecd.org/social/family/43199641.pdf] cited on 11 May 2014.

13. Artazcoz L, Cortès I, Borrell C, Escribà-Agüir V, Cascant L: Gender perspective in the analysis of the relationship between long work hours, health and health-related behavior. Scand J Work Environ Health 2007, 33(5):344-350.

14. Whitfield JB: Gamma glutamyl transferase. Crit Rev Clin Lab Sci 2001, 38(4):263-355

15. Lee $\mathrm{DH}$, Blomhoff $\mathrm{R}$, Jacobs DR Jr: Is serum gamma glutamyltransferase a marker of oxidative stress? Free Radic Res 2004, 38(6):535-539.

16. Lee DH, Silventoinen $K, H u$ G, Jacobs DR Jr, Jousilahti P, Sundvall J, Tuomilehto J: Serum gamma-glutamyltransferase predicts non-fatal myocardial infarction and fatal coronary heart disease among 28,838 middle-aged men and women. Eur Heart J 2006, 27(18):2170-2176.

17. Ruttmann E, Brant $\sqcup$, Concin H, Diem G, Rapp K, Ulmer H: $y$-Glutamyltransferase as a risk factor for cardiovascular disease mortality: an epidemiological investigation in a cohort of 163944 Austrian adults. Circulation 2005, 112(14):2130-2137.

18. Wannamethee G, Ebrahim S, Shaper AG: Gamma-glutamyltransferase: determinants and association with mortality from ischemic heart disease and all causes. Am J Epidemio/ 1995, 142(7):699-708.

19. Yi KN, Kwon OH: Clinical Pathology File. 3rd edition. Seoul: Euihak Munwhasa Co; 2000:370. Korean

20. OECD STAT: OECD STAT Extracts: Average Annual Hours Actually Worked per Worker. http://stats.oecd.org/Indexaspx?DatasetCode=ANHRS [cited on 11 May 2014]

21. Ministry of Government Legislation: Labor Standards Act Article. Laws on Green Growth, and Economic Investment in Korea; 983-985. http://world. moleg.go.kr/World/EastAsia/KR/law/14466 [cited on 11 May 2014].

22. International Labour Office: Decent Working Time: Balancing Workers Needs With Business Requirements. Geneva, Switzerland: International Labour Organization; 2007:3. http://www.ilo.org/travail/whatwedo/publications/ WCMS_145391/lang-en/index.htm [cited on 11 May 2014].

23. European Commission: Proposal for a Directive of the European Parliament and of the Council Amending Directive 2003/88/EC Concerning Certain Aspects of the Organization of Working Time. Brussels, Belgium: European Commission; 2004:11. http://ec.europa.eu/social/main.jsp? catld=706\&langld=en\&intPageld=205 [cited on 11 May 2014]

24. Ministry of Employment and Labor: Survey Report on Labor Conditions by Employment Type. Sejong, Korea: Ministry of Employment and Labor; 2012:22. Korean

25. OECD: OECD Factbook 2013 Economic, Environmental and Social Statistics: Hours Worked. Paris, France: OECD publishing; 2013:140. http://www.oecd-ilibrary.org/ economics/oecd-factbook-2013/hours-worked_factbook-2013-56-en [cited on 11 May 2014].

26. Shields M: Long working hours and health. Health Rep 1999, 11(2):33-48. 37-55(Fre)

27. Steptoe A, Wardle J, Lipsey Z, Mills R, Oliver G, Jarvis M, Kirschbaum C: A longitudinal study of work load and variations in psychological well-being, cortisol, smoking, and alcohol consumption. Ann Behav Med 1998, 20(2):84-91.

28. Virtanen M, Ferrie JE, Gimeno D, Vahtera J, Elovainio M, Singh-Manoux A, Marmot MG, Kivimäki M: Long working hours and sleep disturbances: the Whitehall II prospective cohort study. Sleep 2009, 32(6):737.

29. Onat A, Can G: Serum Y-glutamyltransferase: Independent predictor of risk of diabetes, hypertension, metabolic syndrome, and coronary disease. Obesity 2011, 20(4):842-848.

30. Saijo Y, Utsugi M, Yoshioka E, Horikawa N, Sato T, Gong Y, Kishi R: The relationship of gamma-glutamyltransferase to $C$-reactive protein and arterial stiffness. Nutr Metab Cardiovasc Dis 2008, 18(3):211-219.

31. Kim KN, Kim KM, Lee DJ, Joo NS: Serum gamma-glutamyltransferase concentration correlates with Framingham risk score in Koreans. J Korean Med Sci 2011, 26(10):1305-1309.

32. Nilssen $\mathrm{O}$, Forde $\mathrm{OH}$, Brenn $\mathrm{T}$ : The Tromso study. Distribution and population determinants of gamma-glutamyltransferase. Am J Epidemiol 1990, 132(2):318-326.

33. Nakanishi N, Nakamura K, Suzuki K, Tatara K: Lifestyle and serum gammaglutamyltransferase: a study of middle-aged Japanese men. Occup Med (Lond) 2000, 50(2):115-120.
34. Higashikawa A, Suwazono Y, Okubo Y, Uetani M, Kobayashi E, Kido T, Nogawa K: Association of working conditions and lifestyle with increased serum gamma-glutamyltransferase: a follow-up study. Arch Med Res 2005, 36(5):567-573.

35. Knutsson A: Relationships between serum triglycerides and gammaglutamyltransferase among shift and day workers. J Intern Med 1989, 226(5):337-339.

36. Morris JK, Cook DG, Shaper AG: Loss of employment and mortality. BMJ 1994, 308(6937):1135-1139.

37. Pickering TG, Devereux RB, James GD, Gerin W, Landsbergis P, Schnall PL, Schwartz JE: Environmental influences on blood pressure and the role of job strain. J Hypertens Supp/ 1996, 14(5):S179-S185.

38. Kawakami N, Araki S, Haratani T, Hemmi T: Relations of work stress to alcohol use and drinking problems in male and female employees of a computer factory in Japan. Environ Res 1993, 62(2):314-324.

doi:10.1186/s40557-014-0040-

Cite this article as: Park et al.: Association between long working hours and serum gamma-glutamyltransferase levels in female workers: data from the fifth Korean National Health and Nutrition Examination Survey (2010-2011). Annals of Occupational and Environmental Medicine $201426: 40$

\section{Submit your next manuscript to BioMed Central and take full advantage of:}

- Convenient online submission

- Thorough peer review

- No space constraints or color figure charges

- Immediate publication on acceptance

- Inclusion in PubMed, CAS, Scopus and Google Scholar

- Research which is freely available for redistribution

Submit your manuscript at www.biomedcentral.com/submit
C Biomed Central 